\title{
Beyond the Boundaries of Private Spaces: Women and the Spanish Court
}

\section{Trevor J. Dadson \& Laura S. Muñoz Pérez}

To cite this article: Trevor J. Dadson \& Laura S. Muñoz Pérez (2016): Beyond the Boundaries of Private Spaces: Women and the Spanish Court, Bulletin of Spanish Studies, DOI: 10.1080/14753820.2016.1219527

To link to this article: http://dx.doi.org/10.1080/14753820.2016.1219527

\section{Published online: 31 Aug 2016.}

Submit your article to this journal $\lceil\pi$

Q View related articles $\widetilde{ }$

View Crossmark data $\nearrow$ 


\section{Beyond the Boundaries of Private Spaces: Women and the Spanish Court}

\author{
TREVOR J. DADSON \\ Queen Mary University of London
}

\& $\quad$ LAURA S. MUÑOZ PÉREZ

University of Oxford

\section{Women and the Spanish Court}

Trevor J. Dadson

It is often assumed that women were the silent majority in Early Modern Spain, or, to put it more accurately, the silenced majority. Majority they almost certainly were: the mortality rate among young men was high-the perils of war, travelling (often long distances and abroad), emigration and dangerous occupations - even though women suffered of course from death in childbirth, and from some of the above factors, though proportionately less. ${ }^{1}$ Demographic studies show large numbers of widows among the Spanish population of towns and villages in the sixteenth century, and widows of all ages. Whether it was the perfect state for women, thus underlining the popular concept of the 'Merry Widow' or 'Viuda alegre', is not certain, but widowhood in Early Modern Spain certainly conferred upon women a status they did not have as wives, sisters or daughters: for the first time in their lives they could litigate, defend themselves in the courts, run their own affairs without recourse to a male, manage large estates or professional businesses, often very successfully, and bring up their children as they saw fit. ${ }^{2}$ Married women, for example, had to have a special licence or permission from their husbands to be able to carry out any legal process, even when it had to do with their own estates, money or inheritance. ${ }^{3}$

1 See Allyson M. Poska, Women \& Authority in Early Modern Spain: The Peasants of Galicia (Oxford: Oxford U. P., 2005), especially Chapter 1, 'Women without Men' and Chapter 5, 'Widowhood'.

2 The now standard work on the subject is Grace Coolidge, Guardianship, Gender, and the Nobility in Early Modern Spain (Farnham: Ashgate, 2010).

3 Examples of this can be found in documents of the Princess of Éboli taken out when she was married to Ruy Gómez de Silva. See Trevor J. Dadson \& Helen H. Reed, Epistolario 
Aristocratic widows were thus a powerful group or lobby with considerable resources at their disposal, and Philip II for one was very wary of them. He had two of them locked up, to keep them away from court and what he saw as their meddling in political matters: Jane Dormer, Countess of Feria and Ana de Mendoza y de la Cerda, Princess of Éboli. ${ }^{4}$ This was an attitude shared by others at court, as the following note from the Count of Tendilla to Mateo Vázquez shows:

[...] tiene su majestad en parte gran culpa de esto en consentir cuantas viudas quieren estar en esta corte sin tener para qué. $\mathrm{Y}$ aunque tuvieran negocios de mucha importancia, no habían de asomar a ella, pues no les faltarían hijos ni parientes que viniesen a ellos, y se excusarían mil pesadumbres y deshonras. ${ }^{5}$

The letter was written less than a week after the arrest and imprisonment of the Princess of Éboli on 29 July 1579, to which it makes direct reference. It is certainly interesting to see the king being blamed for this situation and accused of weakness for allowing so many widows at court!

And yet, in spite of the important, at times crucial, role women played in Early Modern Spanish society, we know so little about them. Paradoxically, we know more about the women who were supposedly not involved in society, those who were locked away through choice: nuns and other religious women. Much fascinating research, especially by North American scholars, has been conducted on nuns, their education in convents and their writings, many of which have survived in the convents in which they lived and wrote. The wealth of material now available on writing nuns has overshadowed somewhat the situation as regards secular women. In this joint paper, Dr Laura Muñoz Pérez and I hope to go some way to putting that right and shedding a little more light on secular women, their writing, their patronage of literary and other artistic works, and their relationships with men at the Spanish court. My contribution will look at the general context in which these women worked, and will begin with their education -or lack of it.

Most studies of women's literacy in this period come up with figures at or close to $0 \%$, i.e. they were not literate, they could not read or write. I suspect

e historia documental de Ana de Mendoza y de la Cerda, princesa de Éboli (Madrid: Iberoamericana/Frankfurt am Main: Vervuert, 2013), documents 15 \& 22.

4 For both, see Helen H. Reed \& Trevor J. Dadson, La princesa de Éboli: cautiva del rey. Vida de Ana de Mendoza y de la Cerda (1540-1592) (Madrid: Marcial Pons Historia-CEEH, 2015), and Esther Alegre Carvajal, 'Ana de Mendoza y de la Cerda, princesa de Éboli y duquesa de Pastrana (Cifuentes, 1540-Pastrana, 1592)', in Damas de la Casa de Mendoza: historias, leyendas y olvidos, dir. Esther Alegre Carvajal (Madrid: Polifemo, 2014), 578-617 (p. 614).

5 Hispanic Society of America, Altamira, 7-II-8, dated 4 August 1579. 
that the problem here has more to do with the methods we employ to measure literacy than with women's actual literacy or lack of it. To begin with, there is a general assumption that girls did not go to school. What schools existed were solely for boys, and boys of a certain social class and above, certainly not for all. When we come across the terms 'Maestro de niños' or 'Escuela de niños', the assumption is that 'niños' refers to the masculine plural, ignoring the fact that in Spanish it can and often does refer to both sexes. Evidence for the schooling of girls will most likely come from the Inquisition records. Some years ago I came across the testimony of one Jerónima de Mendoza, a Granada Morisca from Pastrana. Accused of heresy in 1617, at the age of twenty-two, she made a strong defence of her Christianity, stating at one point in her testimony that 'sabe leer y escribir un poco y que la enseñó Juan de Llana, maestro de niños de Pastrana'. ${ }^{6}$ In Pastrana at least girls clearly attended the local school. In Almagro, in the Campo de Calatrava, as a result of inquisitorial investigations into the behaviour and religious practices of the Granada Moriscos, the fourteen-year-old Inés López ended up before the Inquisitors accused of having said that the Moriscos worshipped a donkey and that one of them dressed up as a priest and said Mass in front of it. She naturally enough denied the accusation, but one of the women who had been present at the time, another Morisca, María de Córdoba, said that she considered her to be a deceiving and lying girl and that no account should be taken of anything she said. She knew Inés López well as she had taught her in her role as 'Maestra de niñas'. ${ }^{7}$ Was she employed by the Town Council, did she run a sort of Dame School from her own house? We do not know, but the testimony is evidence of schooling being available to young girls even in a rural environment. ${ }^{8}$ Girls could also of course receive a rudimentary education from the many female religious houses scattered all over the country, as in the case of Teresa Sánchez de Cepeda y Ahumada (Teresa of Ávila). After having learned to read and write at home, she was sent to the Augustinian convent of Santa María de Gracia in Ávila to improve her education, and there she spent a year and a half under the tutelage of Sor María Briceño and the Augustinian chaplain Fray Francisco Nieva. ${ }^{9}$

Until recently, it was a commonplace to assume that any library or books belonging to a woman were merely in transit between a husband, or other relative, to a son; she simply looked after them until the 'rightful' male

6 Archivo Histórico Nacional [AHN], Inquisición, Legajo 195, Expediente 26.

7 AHN, Inquisición, Legajo 496/3, f. 255 .

8 See Trevor J. Dadson, 'Literacy and Education in Early Modern Rural Spain: The Case of Villarrubia de los Ojos', in The Iberian Book and Its Readers: Essays for Ian Michael, ed. Nigel Griffin, Clive Griffin \& Eric Southworth, BSS, LXXXI:7-8 (2004), 1011-37.

9 Elizabeth Teresa Howe, Education and Women in the Early Modern Hispanic World (Aldershot/Burlington: Ashgate, 2008), 61. 
owner was able to take them on. Available evidence suggests that this was not always the case and that many women built up substantial libraries containing books they were interested in and wanted to read. ${ }^{10}$ Catalina de Silva, wife of Diego Hurtado de Mendoza, second Count of Mélito, had a library of some 300 volumes, a substantial collection for the mid sixteenth century by any standards (and three times that of her philandering husband). We know from letters and documents that she personally bought the books or had agents who did so for her. And these included works in Greek and Latin, in which languages we know from other sources she was proficient, as well as a splendid collection of romances of chivalry. ${ }^{11}$ Francisca de Paz Jofre de Loaysa, the wife of a Flemish merchant living in Madrid, had a collection of some fifty books. Some clearly had belonged to her husband, dead at the time the inventory was made (in 1626), such as books on accounting and mathematics, but others equally clearly were hers. ${ }^{12}$ And the same is true of dozens and dozens of other women who were active in the book market.

Many wives of professional men ended up running their businesses when their husband died or was absent. To do so required the ability to read, write, add up and subtract. An illiterate woman could not, for example, successfully run a print shop as did a number of Cromberger wives ${ }^{13}$ or the widow of Alonso Gómez, who was active as a printer and publisher between 1584 and 1595, or the widow of Pedro Madrigal, María Rodríguez Rivalde, active between 1594 and 1604. Even more remarkable is the case of María de Quiñones, the widow of first of all Pedro Madrigal (son) and then Juan de la Cuesta. When Juan de la Cuesta died in the mid 1620s, María de Quiñones took charge of the print shop and printed under her own name until 1666. Other printers' and booksellers' wives took over the running of the print or book shop until either a son was old enough to take charge or they married another printer or bookseller, which was a frequent occurrence-to keep the business running and in the family. María Gutiérrez, the widow of the

10 For a general survey of women's libraries, see Dadson, Libros, lectores y lecturas: estudios sobre bibliotecas particulares españolas del Siglo de Oro (Madrid: Arco/Libros, 1998), and Pedro M. Cátedra \& Anastasio Rojo Vega, Bibliotecas y lecturas de mujeres: siglo XVI (Salamanca: Instituto de Historia del Libro y de la Lectura, 2004).

11 See Trevor J. Dadson, 'The Education, Books and Reading Habits of Ana de Mendoza y de la Cerda, Princess of Éboli (1540-1592)', in Women's Literacy in Early Modern Spain and the New World, ed. Anne J. Cruz \& Rosilie Hernández-Pecoraro (Aldershot/Burlington: Ashgate, 2011), 79-102. For a full list of the romances of chivalry owned by Catalina de Silva, see Trevor J. Dadson, 'Los libros de caballerías, Don Quijote y sus lectores en el siglo XVII', in Antes y después del 'Quijote' en el cincuentenario de la Asociación de Hispanistas de Gran Bretaña e Irlanda, ed. Robert Archer (Valencia: Biblioteca Valenciana, 2005), 59-78.

12 Her library is studied in Dadson, Libros, lectores y lecturas, Chapter 16.

13 See Clive Griffin, "Brígida Maldonado "Ymprimidora" sevillana, viuda de Juan Cromberger', Archivo Hispalense, 76:233 (1993), 83-117. 
bookseller Cristóbal López (he died young, in 1606), for example, married another bookseller Pedro de Lizao, who lived in the same district of Madrid. As the mother of three very young children and with a large stock of unsold books (5,841 plus 12,575 pliegos sueltos) and all the equipment needed to bind them, she had to protect her children's inheritance by taking on the running of this business, and she seems to have done so for at least six to seven years, since an only daughter born of her second marriage was not baptized until April 1614. ${ }^{14}$

Noble or aristocratic women often had to run large estates while their husbands were absent or if they died in battle or on a dangerous journey, or simply from illness. Such was the case of Ana de Mendoza y de la Cerda, Princess of Éboli, who became widowed at the age of thirty-three and had six young children to raise, all well under the age of majority. With probably no experience or understanding of estate management in 1573, when her husband Ruy Gómez de Silva died, she quickly learnt the business and became a very competent and hands-on manager; in fact, the very opposite of the popular conception of her as wilful, capricious and a spendthrift. ${ }^{15}$ Another noble widow, Antonia de Ulloa, not only had to run the estates of the county of Salinas and Ribadeo for eleven years between May 1580 (death of her husband, the fourth Count) and October 1591 (marriage of her eldest daughter, Ana Sarmiento), she also had to deal with relatives who had their eyes on the inheritance and the vast debts her husband and her father-inlaw had built up over many years. She was so good at the job that she managed to get the interest on the estate's debts lowered and to pay back a number of mortgages on the property. ${ }^{16}$ After 1591 she spent the following years training up her son-in-law so that all her hard work would not go to waste. In this she was also successful, so successful in fact that she is probably the only mother-in-law of Early Modern Spain to have had a sonnet dedicated to her on her death, and a moving one at that. ${ }^{17}$

14 See Trevor J. Dadson, 'La librería de Cristóbal López (1606): estudio y análisis de una librería madrileña de principios del siglo XVII', in El libro antiguo español IV: coleccionismo y bibliotecas (siglos XVI-XVIII), ed. Pedro M. Cátedra \& María Luisa López-Vidriero (Salamanca: Univ. de Salamanca/Sociedad Española de Historia del Libro, 1998), 167-234.

15 Reed \& Dadson, La princesa de Éboli, Chapters 6 \& 7.

16 Information to be found in Trevor J. Dadson, Los moriscos de Villarrubia de los Ojos (siglos XV-XVIII): historia de una minoría asimilada, expulsada y reintegrada, $2^{\text {nd }}$ ed. (Madrid: Iberoamericana/Frankfurt am Main: Vervuert, 2015), Chapter 3. For more on the working relationship between Antonia de Ulloa and Diego de Silva y Mendoza, see also Trevor J. Dadson, 'The Count of Salinas and the Women in His Life', in Perspectives on Early Modern Women in Iberia and the Americas: Studies in Law, Society, Art and Literature in Honor of Anne J. Cruz, ed. Adrienne L. Martín \& María Cristina Quintero (New York: Escribana Books, 2015), 52-71.

17 D. Diego de Silva y Mendoza, Conde de Salinas, Antología poética 1564-1630, ed. \& intro. de Trevor J. Dadson (Madrid: Visor, 1985), Sonnet VII: 'De tu muerte, que fue un breve suspiro'. 
All such women had to have received an education somehow and somewhere. We know from the case of Leonor de Guzmán, eldest daughter of the eighth Duke of Medina Sidonia, that daughters of the aristocracy often sat in on their brothers' classes. ${ }^{18}$ Sons of the nobility were most often educated at home, with a plethora of tutors in different subjects. Rodrigo Sarmiento de Silva, Duke of Hijar, had different tutors for: writing, reading, dancing, grammar, mathematics, cosmography, horse riding, fencing and various athletic pursuits. Ana de Mendoza y de la Cerda, his grandmother, was educated by her extremely well-educated mother, Catalina de Silva, and her even more educated aunt María de Mendoza (who had in turn been a pupil of Álvar Gómez de Castro), and she had her mother's excellent library at her sole disposal. A number of the books were clearly bought for her for educational purposes. ${ }^{19}$ Her eldest daughter Ana was also educated at home, but her mother-in-law, the Countess of Niebla, criticized Ana's lack of education when she arrived as a newly-wed to Sanlúcar de Barrameda in 1574, and had a number of teachers appointed to take charge of her education. When the Princess of Éboli found out about this, she was not surprisingly incandescent with rage, and wrote to her confidante Juan de Escobedo that the Medina Sidonia family should be grateful to have such a beautiful and honourable young lady as their bride, and one who could play the harp so well. ${ }^{20}$

Another and vital source of information on literate women in this period comes of course from their letters, memoirs, literary writings and other documents. Leonor Pimentel, the daughter of the Marquises of Távara, wrote frequently to her guardian, Diego Sarmiento de Acuña, future Count of Gondomar, and also to her paramour Diego de Silva y Mendoza, Count of Salinas. ${ }^{21}$ Over forty of her letters have survived, some from her late teens. She comes across as a witty young lady with an ironic, sometimes sarcastic, sense of humour, someone not afraid to express her opinions, usually strongly held, especially in relation to possible suitors, as the following extract delightfully reveals:

18 'Leonor se educó junto a sus hermanos, procurando no desentonar, por menor, que no por mujer' (Luisa Isabel Álvarez de Toledo, Alonso Pérez de Guzmán. General de la Invencible, 2 vols [Cádiz: Univ. de Cádiz, 1994], I, 427).

19 See Dadson, 'The Education, Books and Reading Habits of Ana de Mendoza y de la Cerda'.

20 Reed \& Dadson, La princesa de Éboli, 293, and Dadson \& Reed, Epistolario e historia documental de Ana de Mendoza y de la Cerda, carta 87, 234-39.

21 On this affair, which lasted for nearly twenty years, see Trevor J. Dadson, 'El conde de Salinas y Leonor Pimentel: cuando se juntan el amor y la poesía', in Spanish Golden Age Poetry in Motion: The Dynamics of Creation and Conversation, ed. Jean Andrews \& Isabel Torres (Woodbridge: Tamesis, 2014), 185-212. 
[...] quiérole decir [she is writing to her guardian, Diego Sarmiento de Acuña] que siempre he aprobado lo que más había de tardar en ser, por si la dilación me valiese de quedarme sin estado; que es que tiene hoy el conocimiento de los hombres no es para echar menos a ninguno. Mis primos me han propuesto uno de doce años con gran ansia de que le apruebe. He visto lo que les debo y por pagarles esta voluntad no he querido ser servidora de su casa. También la tenía en Valladolid y V.m. no ha de venirse a él ni le han de dejar que se creyera esto. Echárale a este niño 7 años más y sin reparar en los pocos suyos me quedara en Castilla la Vieja otros 2. De fuera de ella me han propuesto un segundo, rico y de 34 años, y un grande de 60. Todos parecen extremos. Cuán ruin dicha siempre los hay y por oír de parecer que lo son en mi condición no digo que me huelgo que lo sean ellos. ${ }^{22}$

Other than her letters, which are a rich source of information about her, we have her contributions to Salinas' Motes de Palacio, a courtly or palace diversion in which he was the recognized expert from the end of the sixteenth century through to the 1620s. Leonor contributed with her comments (often satirical) and suggestions for possible motes and their respuestas. These show that she was a dab hand at writing octosyllabic verse. $^{23}$

But she was not alone in this. Some of the Motes de Palacio that have survived (and we have over sixty of them by Salinas) are the originals in which each female participant wrote down their response to the courtier's mote and then signed it. These documents are a very valuable source of information on the Queen's ladies-in-waiting who took part in these festivities. To begin with, they reveal how confident most were in writing and signing their name. For the majority it is not a problem, though for some the act of writing was clearly not a natural one, it did not come easy to them, suggesting a much lower level of literacy. Although these Motes de Palacio require further study on my part, my preliminary findings suggest that they were often a coded court game, in which some of the courtiers and the ladies-in-waiting used the opportunity to flirt with each other. Since the man went first with his mote, and it was the lady who responded, this gave these young (and not so young) women a clear advantage and the opportunity to dictate the tone of the diversion. Just like the courtly festivities of the late fifteenth century so brilliantly analysed by Keith

22 Autograph letter to Diego Sarmiento de Acuña, Valladolid, 2 April 1608 (Real Academia de la Historia, Salazar, A-81, ff. $16^{\mathrm{r}}-17^{\mathrm{r}}$ ).

23 See Dadson, 'El conde de Salinas y Leonor Pimentel', and Diego de Silva y Mendoza, Conde de Salinas, Obra completa. I. Poesía desconocida, ed., estudio \& notas de Trevor J. Dadson (Madrid: Real Academia Española, Centro para la Edición de los Clásicos Españoles, 2016), especially pp. $71^{*}-85^{*}$. 
Whinnom and Ian Macpherson back in the 1980s (and earlier), ${ }^{24}$ these Motes de Palacio were also full of in jokes and coded references, some no doubt of a sexual or at least risqué nature. ${ }^{25}$

One of the participants in the 1620s was a certain Antonia de Mendoza. She took part in Salinas' Mote de Palacio 'Perpetuo aborrecimiento / no puede ser sin memoria', which he wrote in 1624 for the festivities organized for the wedding of the Count-Duke of Olivares' daughter, María de Guzmán, with Ramón Pérez de Guzmán, Marquis of Toral. ${ }^{26}$ Antonia de Mendoza later went on to become Countess of Benavente, when she married the Count in 1648. But before then, she was famously the 'Antandra' of numerous pastoral ballads dedicated to her by the Madrid poet Gabriel Bocángel y Unzueta and written mostly during the 1620s and 1630 s, though he was still praising her in his poems up to $1647 .{ }^{27}$ She was also herself a poet, if we are to believe Juan Pérez de Guzmán, who, in a marginal note in MS 3889 of the Biblioteca Nacional de España, Madrid, wrote that most of the poems in this volume were by the Marquis of Velada (who put the volume together) and Antonia de Mendoza. She also organised literary academies in her house and, just as Leonor Pimentel had aided Salinas in the composition and organization of his Motes de Palacio, so too did Antonia de Mendoza with one don Jaime Manuel, possibly Jaime Manuel de Cárdenas y Manrique de Lara (born in 1586), a member of the king's chamber and brother to the Duke of Maqueda, to which title he succeeded in 1644. A further and very curious point of contact between the two women was that both ended up marrying a Count of BenaventeLeonor Pimentel in October 1622 and Antonia de Mendoza in May 1648. They would also have known each other as participants in Salinas' Motes de Palacio.

Literary academies were another venue for women to show off their literary skills. We know from various descriptions of these academies that

24 Keith Whinnom, 'Hacia una interpretación y apreciación de las canciones del Cancionero General de 1511', Filología, 13 (1968-69 [1970]), 361-81; Keith Whinnom, La poesía amatoria de la época de los Reyes Católicos (Durham: Univ. of Durham, 1981); Ian Macpherson, 'Secret Language in the Cancioneros: Some Courtly Codes', BHS, 62:1 (1985), 51-63; Ian Macpherson, 'Conceptos e indirectas en la poesía cancioneril: el Almirante de Castilla y Antonio de Velasco', in Estudios dedicados a Leslie Brooks: presentados por sus colegas, amigos y discípulos, ed. J. M. Ruiz Veintemilla (Barcelona: Puvill Libros, 1984), 91105; Ian Macpherson, 'The Admiral of Castile and Antonio de Velasco: Cancionero Cousins', in Medieval and Renaissance Studies in Honour of Robert Brian Tate, ed. Ian Michael \& Richard A. Cardwell (Oxford: Dolphin Book Co., 1986), 95-107.

25 For more on this, see the Introduction to my edition of Salinas' unknown poetry, mentioned above in note 23.

26 Salinas, Obra completa. I. Poesía desconocida, poema 103, pp. 134-49.

27 See Trevor J. Dadson, La Casa Bocangelina: una familia hispano-genovesa en la España del Siglo de Oro, Anejos de RILCE 7 (Pamplona: EUNSA, 1991), 139-42. 
women were present, but we also know from the lists of participants and prize winners that women did more than just turn up to watch: they participated with poems of their own and often won a particular contest or certamen. The beatification of Teresa de Jesús in 1615 and the canonization of Ignacio de Loyola, Francisco Javier and Teresa in 1622 offered a very public venue for women to show off their poetic skills. One wonders how many of the socalled anonymous compositions that made up the printed relations of these events were in fact by women.

Other than showing considerable skill in writing octosyllabic verse, the queen's ladies-in-waiting were the eyes and ears of husbands, fathers, brothers and, in some cases, sons. As part of the queen's household, which was separate from that of the king, occupying in the Alcázar Real of Madrid its own wing of the palace and courtyard, they had privileged access to her. For the men who thought that they controlled the political agenda, it was crucial to know what was being talked of or being hatched in this apparently interior, domestic space. Under Margaret of Austria, wife of Philip III, the queen's household became a centre of political power which often worked in opposition to the wishes of the king's favourite the Duke of Lerma. Together with the court of the former Empress María (the king's grandmother) now lodged in the Convent of the Descalzas Reales in central Madrid, these two female households wielded considerable political power, especially given that the king was seen to be a weak monarch totally dependent on his favourite, Lerma. $^{28}$ Lerma, naturally enough, had his own spies in the Queen's household, foremost among them his own wife, Catalina de la Cerda, whom he had had named 'Camarera Mayor' to the queen. Even so, it is probable that he received more opposition from the women at court (led by the queen, who detested his corruption and that of his creatures, Rodrigo Calderón, Pedro de Franqueza and Alonso Ramírez del Prado, and resented his influence over her husband), than he ever did from the male courtiers.

Secular women in Early Modern Spain were not therefore so silent or marginal or so confined solely to an interior domestic space as previous historiography may have led us to believe. They often worked hand in hand with their husbands or fathers or other male relatives, to ensure that the family or families that they represented were well protected in the cut-

28 The standard text here is Magdalena S. Sánchez, The Empress, the Queen, and the Nun: Women and Power at the Court of Philip III of Spain (Baltimore/London: The John Hopkins U. P., 1998). In a number of ways the situation at the start of the seventeenth century - with a female power base not controlled by men-was reminiscent of the court of the Infanta and regent Juana between 1554 and 1559 in Valladolid, which was very much a female court with not just the princess in charge of affairs as regent during her brother Philip's absence in England and the Low Countries, but with the presence also of two former queens: Mary of Hungary and Eleanor of France, who had returned to Spain in 1556 with their brother Charles V when he retired to the Monastery at Yuste. Juana was often at loggerheads with her brother Philip over policy, especially as it affected the finances of Castile. 
throat politics of the period, that their estates were not damaged, alienated or suffered depredation as a result of litigation (litigation over an inheritance or an entailed estate could last generations), ${ }^{29}$ and that the family name was honoured and made eternal through artistic and literary patronage. In all of these areas women could and did play a vital role, often, though not always, in the background. That Philip II had to lock up a number of powerful and rich aristocratic women to silence them is a sure indication of just how powerful they could be.

I have concentrated mainly on the court of Philip III, with an occasional excursion into that of Philip II. Dr Laura Muñoz Pérez, my partner in this joint paper, will now take as a case study a woman-writer and patron—at the court of Philip IV: Ana de Castro Egas.

\section{Ana de Castro Egas and the Spanish Court}

Laura S. Muñoz Pérez

The Baroque period or 'Golden Age' of Spain was governed by the complex interdependence of authors and their noble patrons, for whom the funding of literature was a vital form of propaganda, an integral part of their struggle for rank and power in court society. Important advances have been made in understanding this phenomenon in recent decades; however, little attention has been given to the role of women, although the number of female authors was significant.

In many cases such a phenomenon was manifested in women's support of and access to literary and political circles, as in the examples of the prolific writers Countess María de Guevara and Countess Luisa María de Padilla. Other women such as Ana de Castro Egas (who wrote a eulogy of King Philip III at the command of a powerful faction of nobles) or Ana Caro (who wrote plays and news relations [relaciones] on behalf of the Count-Duke of Olivares, Philip IV's favourite) were directly approached to undertake propaganda. Those facts offer ample evidence of a strong and cohesive alliance between upper-class women and cultural and political factions at court. This is partly a consequence of the social parameters, since the division of gender roles not only imposed certain behaviour on noblewomen, but also on the manner of representing their lineage. While men performed public functions and honoured their ancestors by military feats or political acts, women gave prestige to theirs through their deeds in different spheres: founding convents, giving to charity privately or to institutions,

29 For an insight into litigation in this period and just how long it could last, see Antonio Terrasa Lozano, La Casa de Silva y los duques de Pastrana: linaje, contingencia y pleito en el siglo XVII (Madrid: CEEH/Marcial Pons Historia, 2012). 
and financing artistic works or editions of books, all of which might be considered a sign of female heroism.

These tasks were not merely decorative, but were expected to have a practical function and to foster the transmission of social values, for there were political and family interests behind women's acts at court. We are already familiar with the promotion of books by queens or other royal members; ${ }^{30}$ these cases show that the influence of women in the production process of books or paintings was more complex and relevant than previously thought, but still to be studied are the patronage activities carried out by noblewomen. These will highlight the fact that women had their own cultural agenda in Early Modern society.

Politics and literature are most of the time intertwined; chronicles and propaganda writings have been involved in the course of events of empires, dynasties and rulers. ${ }^{31}$ The Count-Duke of Olivares was very much aware of the basic role that public opinion played in politics. His complex and professional relationship with Quevedo is well known, along with Lope de Vegas' desperation to work under his patronage. ${ }^{32}$ However, we very often forget to mention that there were also female authors who either offered their literary services to the favourite of Philip IV, or played a major role at court in support of Olivares. That was the case of Ana de Castro Egas, who published in 1629 in Madrid her eulogy Eternidad del rey don Felipe III, which contains a special dedication to the Cardenal-Infante, Ferdinand of Austria, son of the deceased king and brother of Philip IV. ${ }^{33}$

30 José Simón Díaz, 'Algunos impresos madrileños raros de la segunda mitad del siglo XVII', Anales del Instituto de Estudios Madrileños, 23 (1986), 517-45; Victoria Campo, 'Modelos para una mujer "modelo": los libros de Isabel la Católica', in Actas del IX Simposio de la Sociedad Española de Literatura General y Comparada, Zaragoza 18 al 21 de noviembre de 1992, 2 vols (Zaragoza: SELGC, 1994), I: La mujer: elogio y vituperio, 85-94; Rosa Chinchilla, 'Juana de Austria: Courtly Spain and Devotional Expression', Rennaissance and Reformation, 28.1 (2004), 21-33.

31 For an enlightening study on how women used propaganda and the power of images to enhance their social and political influence in Early Modern Europe, see The Rule of Women in Early Modern Europe, ed. Anne Cruz \& Mihoko Suzuki (Urbana: Univ. of Illinois Press, 2009).

32 There are several monographs on Quevedo's relationship with Olivares; see Pablo Jauralde Pou, Francisco de Quevedo (1580-1645) (Madrid: Castalia, 1998); Elías L. Rivers, Quevedo y su poética dedicada a Olivares: estudio y edición (Pamplona: Ediciones Universidad de Navarra, 1998); Mariano de la Campa \& Isabel Pérez Cuenca, 'El Conde Duque de Olivares, Quevedo y otros contemporáneos', in Libros de la Corte.es, 5 (2012), 12123; and Carlos M. Gutiérrez, 'Quevedo y Olivares: una nota cronológica a su epistolario', Hispanic Review, 4 (2001), 487-99. Lope's attempt to work under Olivares' protection has not drawn so much attention; for a general approach see Laura S. Muñoz Pérez, 'Dejé los libros y arrojé la pluma: Lope de Vega y el desencanto por el mecenazgo cortesano', in El duque de Medina Sidonia: mecenazgo y renovación estética, ed. José Manuel Rico García \& Pedro Ruiz Pérez (Huelva: Univ. de Huelva, 2015), 409-16.

33 Ana de Castro Egas, Eternidad del rey don Filipe Tercero nuestro señor, el piadoso (Madrid: Viuda de Alonso Martín, 1629). There are few extant copies, possibly only four in 
The book was printed by the famous widow of Alonso Martín, who was responsible for the edition of some of Lope's and Cervantes' works. It was presented in an elegant and sumptuous edition, including a long list of paratexts or preliminary writings, among which we can call attention to the poems written by well-known authors such as Lope de Vega, fray Hortensio Félix Paravicino and Francisco de Quevedo, among many others. $^{34}$

Apart from the success of this task, the luxury edition in which it appeared, and the participation of the most celebrated writers of the time in the paratextos, we have very little knowledge of the author. Her public image is almost unknown to us. According to Lope's words in his Laurel of Apolo (1630), ${ }^{35}$ Ana de Castro was Castilian, of noble origin and a member of the power elite at the court, which leads us to believe that she was involved in courtly matters. Apparently, she participated in many justas poéticas and academias literarias under the name of Anarda; this piece of information seems to be true given that many of the writers who collaborated in the preliminaries of Eternidad del rey don Felipe III refer to her as the famous poet Anarda. ${ }^{36}$ For this reason, the large number of writers that signed the preliminaries, where we can also find the names of José de Valdivieso, Juan Pérez de Montalbán, Mira de Amescua, Gabriel Bocángel y Unzueta and Antonio de Herrera, is particularly remarkable. If we compile and compare these names, we realize that the vast majority were related to politics, courtly matters, or were particularly willing or keen to obtain aristocratic patronage ${ }^{37}$ And what is more surprising, most of them took part in the controversy over the new gongorista style. Along with these coincidences we must consider the date of publication, 1629, the year of the popular Programa de reformas of the Count-Duke of Olivares. The fact that this eulogy defends the virtues of the deceased king and there is a

different libraries: British Library, London: 1485aaa37; Biblioteca Nacional Española, Madrid: R-8338; Bibliothèque Nationale, Paris: 8-OC-386; Österreichische Nationalbibliothek, Vienna.

34 We should frame this eulogy within a literary trend that took place in the late $1620 \mathrm{~s}$ with the aim of vindicating the moral virtues of the deceased king, Philip III. Related to that wave of propaganda, we find publications such as Baltasar Porreño, Dichos y hechos del señor rey don Felipe III, el Bueno (1626) (Biblioteca Nacional Española, MS 1736), Gil González Dávila, Historia de la vida y hechos del ínclito monarca, amado y santo don Felipe Tercero (1632) (BNE, MS 1257); or see Hortensio Félix Paravicino, 'Oración fúnebre', in Oraciones evangélicas y panegíricos funerales (Madrid: María de Quiñones, 1641), which was dedicated to the Cardenal-Infante.

35 Lope de Vega Carpio, Laurel de Apolo con otras rimas (Madrid: Juan González, 1630), f. $10^{\mathrm{r}-\mathrm{v}}$.

36 See the examples in Ana de Castro, Eternidad del rey don Felipe III, f. ${ }^{\mathrm{r}}$, f. $11^{\mathrm{r}}$, f. $14^{\mathrm{v}}$, f. $18^{\mathrm{v}}$, f. $20^{\mathrm{r}}$, f. $23^{\mathrm{v}}$, f. $24^{\mathrm{r}}$, f. $27^{\mathrm{r}}$, f. $27^{\mathrm{v}}$, f. $30^{\mathrm{r}}$, f. $31^{\mathrm{r}}$, f. $32^{\mathrm{r}}$, f. $32^{\mathrm{v}}$, f. $33^{\mathrm{r}}$.

37 Quite a few (such as Valdivieso and Bocángel) were already members of the household of the Cardenal-Infante Ferdinand, thus their presence is not surprising. 
positive mention of his favourite has led some critics to consider the book as an implicit criticism against the new Olivares regime. ${ }^{38}$

Eternidad del rey don Felipe III seems to be an enigmatic example of the complexity of Baroque culture and the participation of women in it, in the light of the large number of poets included in the preliminaries, their participation in one of the most influential literary controversies of Spanish literature, the possible opposition to the new regime, and the figure of the author, who, unknown to us, was, nevertheless, popular in her time. The exaltation of the virtues of Philip III, several years after his death, seems suspicious when the new government was trying to consolidate its power through the implementation of various reforms. None the less, a close reading of all the names appearing in the preliminaries reveals aristocrats and nobles such as: the Marquis of Siruela, brother-in-law of Olivares; the Counts of Alcañizas and La Roca, apologists of Olivares; and Antonio Carnero, secretary of Olivares. The inclusion of such names in the paratexts of the eulogy does not indicate a desire to discredit Olivares' government through the exaltation of the deceased king and the mention of his favourite, but, rather, a desire to cultivate the new political regime and attract its attention in order to obtain Olivares' patronage. This interpretation seems to be corroborated by Ana de Castro's words addressed to the young King Philip IV:

Ya quiera Dios que goce su majestad premiado con felicísimos sucesos, el deseo afectuoso de nuestro bien, y la fiel intención del conde duque, pues vemos, que ofreciéndose incansable al mayor trabajo de esta monarquía, asiste solo a la ocupación de muchos, para que de todas maneras se deba a su cuidado la buena dirección en los acertamientos del gobierno. (f. 9v)

This is an attempt to justify the presence of the valido by the king's side to bear the harsh burden of the government; although it is also a flattering exaltation of Olivares. Sure enough, Ana de Castro confirms once again her admiration and support for the favourite:

Es casi forzoso que los reyes tengan inferior compañía en lo pesado del gobierno, y a Dios pedimos mercedes por medio de sus amigos los Santos ya parece que fue comodidad del rey y bien de los reinos aconsejarle con uno de los más fieles y liberales vasallos que se ha visto, ni leído en crónicas de otros reyes aunque han tenido todos privados. (f. $4^{\mathrm{v}}$ )

38 For further information, see Carmen Peraita Huerta, 'Apacible brevedad de los renglones, abreviada vida de monarcas: Ana de Castro Egas, Francisco de Quevedo y la escritura del panegírico regio', La Perinola: Revista de Investigación Quevediana, 9 (2005), 151-70. 
These words are far from being a provocation to the head of the empire. Furthermore, a few years earlier, in 1627, Quevedo had written a play entitled Cómo debe ser el privado to flatter Olivares. The play aims to illustrate the ideal of a perfect State and proposes methods for ruling effectively and according to Catholic principles. This work helps us to identify some of the reasons that were to lead Quevedo to collaborate in the composition of Ana de Castro's book; for what the author of la Eternidad del rey Felipe III emphasizes is how the king should apply religious morality and virtues.

Far from criticizing the political strategies pursued by the Count-Duke, Ana de Castro seeks to please the new valido with her eulogy, which was published at a time of relative hope and positive expectations of the new government. Furthermore, this praise contains elements intended to draw the attention of the powerful elite to its author, in the hope of being invited to work under Olivares, and being paid by him, as one of his propaganda writers. This is evident from the way that Castro reveals her appreciation of the protection of the Cardenal-Infante, as well as from the repeated references to authors of similar writings that figure in the preliminaries. Castro mentions, for instance, the favourable reception given to the public festivities organized to celebrate the marriage between Philip III and Margaret of Austria and goes on: 'Quien escribió de esto dará mejor noticia de ello, siendo mi asunto tratar de muerte' $\left(\right.$ f. $8^{\mathrm{r}}$ ). This is surely a reference to Lope de Vega who was the notable writer praising the festivities; Lope not only contributed a sonnet to the Eternidad del rey don Felipe III, but was to flatter the author in other works. In his 'Silva Primera' of the Laurel of Apolo he states that:

\section{La Fama con el vuelo vagaroso, en los tornos del aire sustenida, cual suele en la estendida tierra mirar el águila la presa, miró para esta empresa} a doña Ana de Castro, y no la hallaba, porque en la corte de Filipe estaba. ${ }^{39}$

Although we have a long list of laudatory poems at the beginning of Eternidad del rey don Felipe III referring to Castro, this book is not simply to be regarded as a eulogy written for and supported by a group of her friends. Other references to be found throughout indicate that the book has other deeper intentions. The large majority of authors involved in the book were enemies of Góngora's new poetic style. As a result, the eulogy and its paratexts, while engaged in exalting Philip III, offer countless comments in defence of

39 Lope de Vega, Laurel de Apolo, f. 10v (vv. 649-55). 
an elegant, unostentatious conceptista style; sometimes associating these stylistic features with the essential virtues of the king. For example, Don Alonso Ordóñez, Comendador of Sampayo, states that: 'Del idioma español lustre y decoro, divinidad en tu discurso adoro [...] tú en elegancia y culto peregrina [...] pues dando eternidades te eternizas en clausulas tan breves y elegantes' (f. $16^{\mathrm{v}}$ ). Comments of this kind clearly are intended to criticize gongorismo, understood to be too complex and too pretentious, less elegant, and indulging in distortions of Spanish syntax. Moreover, the prologue, written by Quevedo, celebrates the polished style, elegance and knowledge of the poet responsible for the Eternidad del rey don Felipe III, with numerous references to the purity of its language and, by stressing the value of the conceit in contrast to the excessive materiality of pretentious and ostentatious words, Ana de Castro writing contains

[1]as palabras sin bastardía mendiga de otras lenguas, que en algunos cuadernos por blasonar noticia desaliñan la nota, y cuando mas presumen de joyas, mejor se confiesan manchas. (f. $34^{\mathrm{r}}$ )

Such comments confirm Quevedo's reasons for taking part in the Eternidad del rey don Felipe III, which offered him a splendid opportunity to express his contempt for the style of Góngora and his imitators. Ana de Castro herself begins her writing by praising 'la prosa tan natural de Castilla' (f. $1^{\mathrm{v}}$ ), a comment which closely resembles Lope's words in La Circe (1624), dedicated to Olivares, where he affirms pointedly: 'le envío estos versos en la lengua de Castilla, lengua que se usaba no ha muchos años. ${ }^{40}$ Lope and Quevedo were particularly vehement in their defence of the use of elegant and traditional Castilian, and in expressing their disapproval of Góngora's style of poetry. Lope kept on criticizing gongorismo even after the death of Góngora, a period during which Lope was most active in trying to gain the favour of Olivares. ${ }^{41}$ Quevedo behaves in similar fashion. He published La culta latiniparla against Góngorá's supporters, ${ }^{42}$ and dedicated his edition of fray Luis de León's poems to Olivares, emphasizing that 'son en nuestro idioma el singular ornamento y el mejor blasón de la habla castellana'. ${ }^{3}$

Ana de Castro repeatedly shows the same attitude in her book: defending the elegance and purity of the Spanish language. This book is an attempt to

40 Lope de Vega Carpio, La Circe con otras rimas y prosas (Madrid: Viuda de Alonso Martín, 1624), f. $3^{\text {r }}$.

41 See the aforementioned study: Muñoz, 'Dejé los libros y arrojé la pluma'.

42 Francisco de Quevedo, Juguetes de la niñez y travesuras del ingenio (Madrid: Viuda de Alonso Martín, 1633).

43 Obras de fray Luis de León, ed. Francisco de Quevedo (Madrid: Imprenta del Reino, 1631), f. $9^{\text {r }}$. 
gain authority from within the 'República de las Letras', and thereby obtain powerful support for its author and her circle in their efforts to maintain what they regarded as a superior literary convention, while also protecting and promoting political and religious teachings, customs and traditions.

This intriguing book is important as a means to our deeper understanding of the literary circles, controversies and courtly affairs of baroque Spain, for it shows how the literary abilities of a noblewoman were used by a whole group of prominent writers with the aim of getting closer to the political power of the day, but also of defending a specific poetic style - that practised by the opponents of culteranismo. Góngora's supporters collected his works in what is known as the Chacón manuscript and gave it to Olivares as a gift, by which they sought the favourite's protection and patronage. ${ }^{44}$ It is understandable that Góngora's detractors tried to act strategically within Eternidad del rey don Felipe III, and to use this book as a means of legitimizing and promoting the literary principles they themselves followed in their own creative writings. This brief analysis of Ana de Castro's book shows how a published eulogy could become a vehicle through which to defend, publicize and lend authority to a specific set of poetic principles and techniques, and, at the same time, the means through which to secure patronage and protection from those with power and influence at the Spanish court.*

44 See Obras de don Luis de Góngora. Manuscrito Chacón (Madrid: Real Academia Española, 1991), an edition, with introduction and preface, in which Dámaso Alonso and Pere Gimferrer collaborate. For further information on the relationship between Góngora's supporters and Olivares' patronage, see Jeremy Lawrance, 'Las obras de don Luis de Góngora y el conde-duque: mecenazgo, polémica literaria y publicidad en la España barroca', in Poder y saber: bibliotecas y bibliofilia en la época del conde-duque de Olivares, ed. Oliver Noble Wood, Jeremy Roe and Jeremy Lawrance (Madrid: Centro de Estudios Europa Hispánica, 2011), 157-81.

* Disclosure Statement: No potential conflict of interest was reported by the authors. 